\title{
Abundance, relative home range and species - habitat association of small mammal species in Nyerere National Park, Tanzania
}

\author{
Aenea Saanya ${ }^{1}$, Rhodes Makundi ${ }^{2}$, Loth Mulungu ${ }^{3}$, and Apia Massawe ${ }^{2}$ \\ ${ }^{1}$ Sokoine University of Agriculture College of Forestry Wildlife and Tourism \\ ${ }^{2}$ Sokoine University of Agriculture \\ ${ }^{3}$ Sokoine University of Agriculture Faculty of Agriculture
}

September 24, 2021

\begin{abstract}
Home ranges play an important role in the ecology of small mammals in understanding the driving factors for variations between species, including; mating patterns, foraging behavior and habitat use. We investigated the abundance, relative home ranges and species-habitat association of small mammal species in the Nyerere National Park. Two habitats; closed woodland and seasonal riverine forest were selected and in each habitat two grids of $70 \mathrm{~m}$ x 70m were established. The Capture Mark Recapture technique was deployed. From July 2018 to June 2020 a total of 732 small mammal individuals belonging to 19 species were captured. Of the 19 species captured, 12 were rodents, 2 insectivores, 4 carnivores; and 1 primate. Acomys ngurui abundance was not statistically significant different between habitats $(\mathrm{W}=220, \mathrm{df}=1, \mathrm{p}=0.144)$ and across seasons $(\mathrm{F}(2,45)=1.41$, $\mathrm{p}=0.2547))$. While, Mastomys natalensis and Lemniscomys rosalia were statistically significant different $(\mathrm{W}=407, \mathrm{p}=0.01$ and $\mathrm{W}=430.5, \mathrm{p}=0.002$ respectively) between habitats and across seasons $(\mathrm{F}(2,45)=4.352, \mathrm{p}=0.019$ and $\mathrm{F}(2,45)=6.321, \mathrm{p}$ $=0.0038$ respectively). Acomys ngurui had the largest mean home range size $(1,087.58 \mathrm{~m} 2)$ than L. rosalia (831.55 $\mathrm{m} 2)$ and M. natalensis $(166 \mathrm{~m} 2)$ with overlaps being recorded in habitats and across seasons. Most small mammals were associated with seasonal riverine forest. We conclude that, small mammal species abundance and home ranges vary with habitats and seasons for individual species in the Nyerere National Park. We recommend to the management of the park to consider small mammals in their general management plan.
\end{abstract}

\section{Hosted file}

Updated Saanya_et_al._2021_Home_Range_-_Ecology_and_Evolution_2021.doc available https://authorea.com/users/435389/articles/538449-abundance-relative-home-range-andspecies-habitat-association-of-small-mammal-species-in-nyerere-national-park-tanzania

\section{Hosted file}

Saanya et al. 2021 Figure EE.doc available at https://authorea.com/users/435389/articles/ 538449-abundance-relative-home-range-and-species-habitat-association-of-small-mammalspecies-in-nyerere-national-park-tanzania 